\title{
Determinants of firm value: evidence from listed insurance companies in Indonesia
}

\author{
I Ismiyatun ${ }^{1}$, Nafiah Aryani' ${ }^{1}$, and Heri Ispriyahadi² \\ ${ }^{1}$ Post Graduate of Sahid University Jakarta, Indonesia \\ ${ }^{2}$ STIE Muhammadiyah Jakarta, Indonesia
}

\begin{tabular}{ll}
\hline Abstract & This study was conducted to determine the effect of Return on Asset (ROA), Debt to Equity \\
Ratio (DER), and Current Ratio (CR) on firm value in insurance companies listed in \\
Indonesia Stock Exchange from 2015 to 2019 . The population in this research was 12 \\
companies in various Insurance listed in the Indonesian Stock Exchange. The analytical \\
method used three regression estimations (pooled OLS, fixed effects model (FEM), and \\
random effects model (REM)). The results indicated that the Return on Asset, Debt to Equity \\
Ratio, and Current Ratio had a significant negative effect on firm value. Our key finding from \\
this research showed that when the profit was higher, the companies prefer to hold their \\
earnings and use for an investment to generate growth opportunities. This phenomenon \\
had explained when companies had higher yields, the firm's value went down. Therefore, \\
this research is following the Pecking Order Theory. Further interaction analysis between \\
DER and CR on firm value uncovers that both DER and CR also negatively affect firm value.
\end{tabular}

\section{INTRODUCTION}

Based on financial institutions' empirical data among Asian countries, most of Southeast Asia countries, especially Indonesia, have been dominated by the banking industry. It shows that an insurance market share in Indonesia, both Life and General Insurance is only 10 percent of the financial market. Financial institution especially insurance institution was not getting much attention from regulatory, society and researcher. The presence of insurance institution until now, just like complimentary in financial industry, yet, it is not deniable that the insurance industry took an important role as a partner for the banking industry, which has a function to guarantee banks' risk in distributing credit and supporting the national economy through the community's fund. This situation is very different with others developed countries in Southeast Asia, such as Malaysia and Singapore, whereas insurance become mandatory element in every single part of society. With those background, this study become very important, beside to enrich literature, information and explanation to society, study in insurance institution in Indonesia is still very rare. According to Kasmir (2014), Insurance regulated private or government companies to guarantee compensation for losses, death, illness, and damage, in exchange for particularistic premium payments with a specific period. An insurance policy is an agreement letter that agrees between the insured and insurer that has been mutually agreed. The regulations are written in a document approved by insurance companies, based on the insurer's premium (Sastrodiharjo and Sutama, 2015).

The impact of massive growth in the economic and industrial sectors has a complex effect on Indonesia's insurance business growth. One of the impacts is how to persuade and influence the public that Insurance is essential for their assets and family member. Based on year 2018 data released by Indonesia Financial Authority (OJK), Insurance penetration in Indonesia is still around $12 \%$, which means $88 \%$ of the Indonesian people are still uninsured. Low awareness about Insurance (un-insurance minded) may become one reason for the above condition. Fact in the field showed several causes identified that create lower consciousness of the Indonesian people to Insurance, namely inadequate enforcement from government/regulatory, inferior financial aspect from most of Indonesian people, bad image and performance of the insurance industry, and minimal/less optimal promotion \& socialization conducted by the insurance company. Based on that 
background, causing reluctancy from the investor to proactively invest in insurance industry. Thus, the insurance industry's performance optimization is mandatory with education/insurance literation, building awareness, and building a good insurance image to the public. Since insurance in Indonesia had different type, and condition, only occupied small portion in financial industry, causing insurance company been neglected, thus study in insurance company using listed insurance company in stock market is very important to obtain society and investor trust to aim massive insurance growth. To convince investor that insurance sector has good performance and profitable enough, study using company ratio (ROA, ROE, DER, Current Ratio, Firm Value) become very important. That ratio commonly has been used to measure company performance. According to Harmono (2011), company performance showed the company's condition for a certain period and is reflected in the firm value.

Firm value is probably one of the most critical academic research topics covered in literature over the last few decades. Firm value describes the company's performance and ability to influence investors' decisions (Mahendra, 2012). Firm value can be determined by factors such as the company's ability to generate profits, leverage policy, short liabilities capability and policy, financing policy, the company's size, stock price in the market, profitability, and several factors been concluded through other empirical research. Firm value will be one of the shareholders most significant attention. Therefore, one of the company's missions is to maximize the shareholder's prosperity by maximizing the stock price. Increasing the firm value is a goal from all management decisions in financial and it can be achieved by maximizing income or profit from the shareholders (Harmono, 2011). One of the parameters that can show firm value is the stock price. Stock price reflects the firm value, which all investor and shareholders expected a maximum benefit from it. As reflected in the stock market's price stock, the shareholders' prosperity can be maximized by the management of the company with several activities, namely investment policy, leverage policy, and dividend policy (Sunaryo \& Adiyanto, 2017).

The company's financial statements are vital critical reports used by shareholders and investors to get information about its performance, financial condition, and alteration in the financial position. Excellent financial performance able to indicate that the company has a promising future. Hamidah \& Umdiana (2017) said a series of financial ratios, namely, leverage ratios, profitability ratios, asset management, liquidity ratios, and market value ratios, could be used to assess the company's financial performance. The company's vision and mission can be achieved through the right strategic plan and proper execution in every management function. All decisions in the financial aspect of management will affect every aspect, not limited to firm value. The optimal balance position and combination of management decisions in the finance aspect, namely budgeting policy, liquidity policy, funds policy, investment policy, debt policy, capital structure policy, and determination on dividend, will affect firm value. Every decision and policy made by the management will be correlated to one another (Ernayani et al., 2017).

The insurance industry uses various financial ratios, even these measures are insufficient for performance evaluation, though they produced vital information. Some financial ratios that commonly been used by industry are profitability ratio, leverage ratio, and liquidity ratio.

Profitability is an essential requirement to maintain the long-term sustainability of a firm. It shows a ratio that reflects and has a significant effect on the company's financial goals achievement, and it can significantly affect firm value. In this study, profitability ratios used to calculate a company's achievement are ROA (return on assets). According to Gitman and Zutter (2012), return on asset is the net income achievement from a company's financial statements based on profit generation. The company's performance rating will be attributed to the return on investment.

Other elements that influence firm value had been debate widely in several researches. One of the factors is capital structure and leverage. The discussion is focused on the optimal possibility of capital structure ratios in the company or the ratio of leverage that can raise the firm value (Handriani \& Irianti, 2015). Most researchers agree that most of the company's value is determined by debt structure or leverage. The operational activities spending in each company can be described used leverage ratio to represent the size of the debt used 
by the firm in operating activities. In most companies, decisions and policies in leverage are crucial since a high leverage ratio can increase company value due to a tax protection policy. According to Jacoby \& Zheng (2013), they suggested that the company apply optimum capital structure decisions to maximize the company value since they discover that firm value can increase by capital structure policy. Therefore, the company's high increment profitability will be helped by smart decisions of the right proportion of leverage and capital in the capital structure. Thus, one of the critical components in profitability is capital structure. The increment in firm performance cannot be separated from the company capital structure aspect. Managing ratio on capital structure to improve the company's profitability and liquidity, which can increase the firm value, is categorized as one effort made by the company to improve company achievement.

Other than profitability and leverage ratio, liquidity also considers an essential element in the earnings area since liquidity shows the amount of working capital needed by the company to finance the company's operational activities. Excellent plan, control, and monitor of the company's liquidity are essential to the firm because they can mitigate and avoid the company's risk from short-term liability failure and excessiveness of the current assets.

On the other hand, if the company's CR is too high, it may show that the firm is not efficient. The firm utilizing short-term financing facilities or their current asset and create a higher current ratio, which can affect for a company to lose the investment opportunity to generate profit.

Hossain \& Hossain (2015) explained that asymmetric information becomes the base of the signaling theory. In that case, managers send signals to the public/investor using debt/leverage policies. Investors will see that the company was financing its activities through debt as a good signal that the company will have high potential prospects. The combination of capital structure, liquidity, and profitability can intervene in company value due to the Insurance's company characteristic required significant funds for their operational processes. Hermawan \& Maf'ulah (2014) explained that profitability has a negative effect on firm value, Ulya (2014) demonstrated that profitability and liquidity positively affect firm value. Other studies from Acaravci (2015) explained that most research had been conducted, reveal that there are no patterns and consistency in theoretical predictions regarding the relation of profitability on firm values.

Based on that description, where we can find research gaps in every research, this study was conducted to discover the direct effects of capital structure, profitability, and liquidity on firm value in the insurance industry listed on the Indonesia Stock Exchange (IDX). Studies in theoretical methods conducted together with the empirical research illustrate each variable and the correlation between variables supporting arranging hypotheses. Based on this research, our expectation that this thesis study can provide theoretical and practical contributions regarding the direct correlation of profitability, capital structure, and liquidity on firm value, both partial and simultaneous.

\section{LITERATURE REVIEW AND HYPOTHESES DEVELOPMENT}

Firm value can be described as a perception from the market or investor and often correlated with stock prize (Harmono, 2011). Firm value also can be defined as present value that reflected the generating cash flow that the company will earn in the future (Sunaryo \& Adiyanto, 2017). The company's value in this research is formulated by the Tobin's $Q$ ratio, wherein Tobin's $Q$ ratio comparing the market value of a firm's liabilities and equity with its corresponding with the value of the company assets' replacement or book values. Market value is the price at which securities are quoted in the stock market at a particular time and calculated by the market actors. Stocks are defined as securities that represent the ownership portion of a company. Shares are usually marketed in the capital market. People who own or provide funds meet with those who need funds facilitated by trading securities with more than one year's maturity. This study uses stocks' market price in the sufficient closing period or closing price on December 31 of each research year to calculate stock price. The formula used to calculate Tobin's $Q$ ratio is as follows (Prasetyorini, 2013):

\footnotetext{
Tobin'sQ $=\frac{\text { (Equity Market Value }+ \text { Liabilities Market Value) }}{\text { (Equity Book Value }+ \text { Liabilities Book Value) }}$
} 
According to Mardiyati et al. (2012), several existing theories related to firm value incorporated with debt structured in the company.

\section{The structured capital approach}

Miller \& Modigliani (1961) discovered that a company's asset's profit determined the firm value. Positive results show that higher profitability results from the more efficient asset's turnover or higher profit margin obtained by the company, impacting the firm value's increment. MM punctuated that companies that use loans will have higher company value than companies that do not use loans. A higher ratio of debt to assets will follow the higher company value reflected by its stock price in the market. But in a specific ratio, continuous increment in debt will not bring a higher increment in firm value because it causes higher risk in the company since higher loans will follow a higher risk of default. It will be making the value of the company getting lower. Or, in other words, increment leverage will increase the company's value to a certain level. Still, the continuously incremental leverage level after the optimum limit will reduce the company's value because it generated a higher risk of corporate debt.

\section{The theory of signaling hypothesis}

According to Bhattacharya and Dittmar (2004), the signaling theory of capital structure is based upon the asymmetrical information's problem between internal which been represented by the Manager, and external parties, which been represented by investors. The company's good news will not announce directly by the Manager to the external since all company's Manager could do the same without valid information. Instead of this, increasing the firm's leverage and capital structure by management is part of its commitment. Thus company with a promising future will not take some risk to undertake. The company is increasing its leverage to send signals to shows good prospects of the company to the public or market. On the contrary, some good company reluctant to take the burden of lending since it will bring bankruptcy risk. Therefore, the Manager often uses capital structure changes to give some information on its profitability and risk to external users and investors.

\section{Trade-off theory}

According to Culata and Gunarsih (2012), the trade-off theory is the combination based on tax research (Modigliani and Miller, 1963), bankruptcy, and costs of financial distress (Warner, 1977), and agency's literature insight (Jensen and Meckling, 1976). They suggest that each company must have a specific formula in the optimal structure of the capital to obtain balancing between tax advantages of the loan financing (i.e., debt tax shields), the costs financials' distress costs, benefits of the agency benefits, and debt's costs, which optimal capital structure can be predicted by trade-off theory. A combination between sources of funds consisting of loan/debt and stock that will result in the highest yield value of the firm will be called optimal capital structure. High stock prices are one indication of the high value of the company. Thus, optimal capital structure is a ratio that generates the highest value of the company. According to Myers (1984), a company that implements the trade-off theory determines a target debt-to-value ratio then gradually shifts towards the goal. The goal is established by balancing from tax shields of debt against bankruptcy costs.

\section{The pecking order theory}

Myers and Majluf (1984) popularized Pecking Order Theory when both argued about less preference of the equity as a tool to increase the capital due to when management in the company (who are assumed to understand better about firm's condition than external/investor) issues new equity, the market will believe that management considers that the company is overvalued, and the management are taking benefit from this situation. As a result, the market will put a lower value for new equity released. Pecking order theory emerges from the concept of asymmetric information, which has been known as a failure of the data. It happens when one side receives more (better) information than others, which causes unbalanced transaction power.

In the Finance industry, pecking order theory postulates that financing costs increase with asymmetric information. Three sources that have been known as financing 
sources are internal funds, debt, and new equity. From those sources of financing, companies will provide prominent their heads with these sequences; firstly, internal financing/funds, second, debt, and lastly, issued new equity as a "last resort."

\section{Return on asset (ROA)}

According to Sulasmiyati (2016), return on asset (ROA) shows the ability to produce a return from shareholders' book value. ROA is a ratio that shows how big the contribution of investments in deriving the net income. This ratio calculates how much each of the funds embedded in the total asset will generate net income. The higher ROA ratio in the company means the higher net profit could be generated from each of the funds diverged in total assets. Conversely, a lower ROA ratio may result in a lower net profit earned by a company. The formula used to calculate ROA is as follows (Annisa \& Chabachib, 2017):

$$
\text { Return on Assets }(\text { ROA })=\frac{\text { Net Profit }}{\text { Total Asset }}
$$

\section{Debt to equity ratio (DER)}

One method to measure leverage ratio is using the Debt to Equity Ratio (DER). Composition of the total debt (loan capital) to total equity (capital) in fulfilling its long-term liabilities reflected in this formula. In simple words, DER is the comparison between total debt versus total equity. Based on (Ang 1997), DER is used to calculate debt usage to the shareholders' whole company's equity. A high DER ratio reflects that the structure of total debt (both short and longterm) is higher than total capital itself, thus influencing the burden on companies to creditors. DER also supplies an overview of the company's capital structure, where we can see the risk level of unsettled debt and corporate debt. Companies with high debt simultaneously have considerable debt costs as well, and it impacts destroying investor's trust level. Investors tend to avoid stocks with a high ratio in debt. When some debts increase in absolute terms, then the company's solvency ratio will decrease, simultaneously with the return of the company's value. Leverage is an important criterion to measure the effectiveness of corporate debt usage (Hery, 2017). The calculation is as follows:

$$
\text { Debt to Equity Ratio (DER) }=\frac{\text { Total Debt }}{\text { Total Equity }}
$$

\section{Current ratio (CR)}

According to Kasmir (2014), liquidity is a comparison that describes a firm's capability to meet short-period (debt) liabilities. Meanwhile, according to Dewantoro and Thaib (2017), liquidity is defined as the firm's ability to meet obligations or debts that must be paid with the current assets. It is used to calculate the firm's capability to meet its short-period liabilities. This measurement can be calculated using information about working capital, i.e., current asset or liquid assets (Brigham \& Houston, 2010). As explained in most empirical literature, the current ratio is one of the tools to measure the company's ability to fulfill short-term liabilities with its existing assets. The resources to complete the mandatory obligations come from cash or the conversion to cash from other current assets sources. According to Fadhli (2013), the calculation of $\mathrm{CR}$ is as follows:

$$
\text { Current Ratio }=\frac{\text { Current Assets }}{\text { Current Liabilities }}
$$

This study will examine the effect of profitability, leverage, and liquidity on financial sector companies with the following framework:

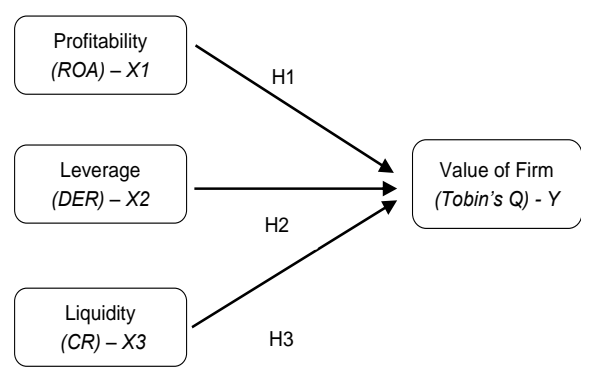

Figure 1.

Research Framework 


\section{Hypotheses development}

According to Bhattacharya and Dittmar (2004), a significant increment in debt ratio will signal that company condition, especially in the profitability of the company, can minimize asymmetry information between internal and external. Therefore, Bhattacarya explained that a high profitability company and increased dividend payments ratio indicate good prospects for the company so that investors will respond positively and its cause increasing on firm value. This research aligned with the theory from Modigliani-Miller stated that profit generated from the company's assets would determine company value. The study by Tahu \& Susilo (2017) stated that the correlation between profitability and firm value has a positive and significant effect. The research results are similar to Hasbi (2015) research, which noted that the correlation between capital structure and firm value has a positive and considerable influence. Zuhroh (2019) found that liquidity and profitability on company value have a positive and significant effect. The research results from Fajaria \& Isnalita (2018) explained that company value can increase significantly, causing profitability.

Based on that information, the hypothesis of this study is:

H1: Profitability has a positive and significant effect on firm value

Most of the research conducted in the financial industry revealed a positive relationship between profitability and firm value proxied through Tobin's $Q$. Company with high profitability will got a positive reaction from the investor, and these positive signals were able to increase firm value.

Most of the results from some study explained that high profitability indicates good company prospects because it shows that the company can generate profit and bring prosperity for investors; therefore, the company's value will increase significantly, simultaneously with the positive response from the market investor. ROA reflects the efficiency of management in managing company assets to generate profit. This result was also confirmed by Fajaria \& Isnalita (2018), Tahu \& Susilo (2017).
H2: Debt structure has a negative and significant effect on firm value

Insurance sub-sector companies are companies that are short/middle-term in nature, so they require significant funds to finance the company's operational and project activities. Third parties' debt becomes one of the company's funds other than the primary revenue from the customer's gross written premium (GWP). In particular condition, loan or debt usage will increase the company's value if the interest costs from debt can reduce corporate tax payments or generate tax deductibles. Still, at a certain level, the increased leverage indicates greater bankruptcy possibilities because the investor will see that the firm will have an obligation to pay installment and interest for that debt. This result was also confirmed by Hertina et al. (2019) and Pratiwi (2018).

H3: Liquidity has a positive and significant effect on firm value

The company's capability to fulfill shortterm financial obligations shows liquidity - a high ratio of liquidity able to interfere with investor mindset to invest their fund in companies. Higher demand for the shares will cause an increment in stock prices. Liquidity is an essential factor in the company because it plays an important role. Research conducted by Yanti \& Dwirandra (2019), stated correlation between liquidity and capital structure has a positive and significant effect. A company that can meet its financial obligations promptly means that the company is in a liquid position and indicates the opportunity to grow from this company is very high. A good liquidity level ratio from the companies will bring that company quickly get additional capital injection and maintain the capital structure that is considered to have good performance by investors (Pervaiz et al., 2012). The research from and Yanti \& Dwirandra (2019) and Cheung et al. (2011) explain that company value influence significantly positive by liquidity. The signaling theory states that a higher level of liquidity of the company proved that they could manage all available resources to maximize the company's operations. It will generate increased profitability and can be used to fulfill short-term liabilities. Therefore, high profits can be a positive signal for investors 
Table 1.

List of samples data

\begin{tabular}{ccc}
\hline No & Issuer code & Issuer name \\
\hline 1 & ABDA & Asuransi Bina Darta Arta, Tbk. \\
2 & AHAP & Asuransi Harta Aman Pratama, Tbk. \\
3 & AMAG & Asuransi Multi Guna Artha, Tbk. \\
4 & ASBI & Asuransi Bintang, Tbk. \\
5 & ASDM & Asuransi Dayin Mitra, Tbk. \\
6 & ASJT & Asuransi Jasa Tania, Tbk. \\
7 & ASMI & Asuransi Mitra Maparya, Tbk. \\
8 & ASRM & Asuransi Ramayana, Tbk. \\
9 & LPGI & Lippo General Insurance, Tbk. \\
10 & MREI & Maskapai Reasuransi Indonesia, Tbk. \\
11 & PNIN & Paninvest, Tbk. \\
12 & VINS & Victoria Insurance, Tbk. \\
\hline
\end{tabular}

to increase the firm value (Fajaria \& Isnalita, 2018).

\section{METHODS}

\section{Population and sample}

This study's population was 12 insurance companies listed in Indonesia Stock Exchange for the period 2015-2019. The method of determining the sample was the census method, which means a way of data collection in which all elements of the population are examined as an individual object.

The sampling applied several specific consisting of a panel data regression model. Panel data regression model is regression analysis that attempted to observe data obtained over multi periods. This statistical method estimates the parameters in crosssectional data using the least squares estimation approach known as Ordinary Least Square (OLS). Panel data is a combination of time-series data (dataset recorded over a specific period) and crosssectional (data collected at one time), meaning that the information does not contain multiple elements, and groups of respondents classify the data itself. The advantage of using panel data regression is when researchers cannot conduct an analysis using only time-series data or cross-section data (Yaomil, 2018). The classical assumption test was conducted after obtaining the best method or approach from panel data. According to Basuki (2017), in panel data regression, classical assumption tests that exist in the OLS method do not necessarily must be taken, yet multicollinearity and heteroscedasticity tests are still fundamental. Hypothesis testing was carried out to determine the result of the partial significance test (t-test) and the F-test of overall significance (TorresReyna, 2014).

\section{RESULTS AND DISCUSSION}

\section{Panel data test}

To get the best panel data regression model, the chow-test and Hausman-test were performed so that the method chosen would match the data characteristics and research objectives. These tests were also conducted to determine which regression model among common effect model (CEM), fixed effect model (FEM), or random effect model (REM) could give more accurate estimation results (Torres-Reyna, 2014). Chow-test is a

Table 2.

Chow test data analysis

\begin{tabular}{crrr}
\hline Effect Test & Statistic & d.f. & Prob. \\
\hline $\begin{array}{c}\text { Cross-section F } \\
\text { Cross-section } \\
\text { Chi-square }\end{array}$ & 44.306655 & $(11,45)$ & 0.0000 \\
& 148.240936 & 11 & 0.0000 \\
\hline
\end{tabular}

Table 3.

Hausman test data analysis

\begin{tabular}{ccrc}
\hline $\begin{array}{c}\text { Test } \\
\text { Summary }\end{array}$ & $\begin{array}{c}\text { Chi-Sq. } \\
\text { Statistic }\end{array}$ & $\begin{array}{r}\text { Chi-Sq. } \\
\text { d.f. }\end{array}$ & Prob. \\
\hline $\begin{array}{c}\text { Cross-section } \\
\text { random }\end{array}$ & 8.209031 & 3 & 0.0419 \\
\hline
\end{tabular}


Table 4.

Multicollinearity test

\begin{tabular}{ccrc}
\hline & \multicolumn{3}{c}{ Correlation } \\
& ROA & DER & CR \\
\hline ROA & 1.000000 & -0.283275 & 0.232684 \\
DER & -0.283275 & 1.000000 & 0.634334 \\
CR & 0.232684 & -0.634334 & 1.000000
\end{tabular}

statistical test to choose the best model between the common effect model (CEM) and the fixed-effect model (FEM).

The result of this test is displayed in Table 2. The econometric test was performed using the E-views program with a confidence level of $95 \%(\alpha=5 \%)$. According to the figure above, the chi-square critical value is 0.0000 , which is less than $\alpha(0.05)$. Thus, the ideal estimation method to be employed is the fixed effect model (FEM).

A Hausman test was then exercised to determine the best regression model between the fixed-effect model (FEM) or the random effect model (REM) after conducting the chow test. The Hausman test results are shown in Table 3, in which the Hausman test was performed employing the E-views program with a confidence level of $95 \%(\alpha=$ $5 \%$ ). The random cross-section value is 0.0419 , where the value is less than $\alpha(0.05)$. Accordingly, the best estimation method to be utilized is the fixed effect model (FEM).

\section{Classic assumptions test}

This classic assumption test aims to determine whether the data collected are feasible for further investigation. Thus, the classic assumption tests exercised in this study are as follows: A multicollinearity test was conducted to measure the intercorrelations between independent variables (Cahyono \& Prabawa, 2011). A regression model ideally should not present any correlation between independent variables. The multicollinearity problem can be found by analyzing the correlation value between tested variables. If the correlation value among variables is more significant than 0.8 , in that case, it can be concluded that there is a multicollinearity problem in the model (Sugiono, 2012).

Table 4 disclosed the statistical results of multicollinearity tests that the researchers had carried out. From the table above, it can be concluded that the correlation value across independent variables used in this study falls below 0.8 . It is, therefore, the dataset that is free from multicollinearity problems.

The heteroscedasticity test is a statistical examination to identify the presence of variance in residual for all observations in the linear regression model. A good regression model should present homoscedastic variance in its random variables, and one of the methods to test heteroscedasticity is to use the Glejser test (Ghozali, 2013). Glejser test regresses the residuals on the explanatory variable that is thought to be related to the heteroscedastic variance (Ernisianturi, 2015). Based on the generated outcome, each data presents homoscedastic. From table 5 , it can be concluded that the variance falls below 0.5 . Therefore, it can be concluded that the research data is present homoscedastic.

\section{Hypotheses testing}

After performing several statistical tests with E-views 11 software, the fixed-effect model (FEM) is the best regression model to be applied in this study. Results that were successfully gathered from the relevant regression test directly answer all the hypotheses in this study. The following are further discussions of the results of the tests. Each independent variable's statistical effect on the dependent variable was carried out by employing a partial significance test (t-test).

From the results captured in table 6 , it can be observed that all independent variables affect the dependent variable. From the results shown, ROA has a negative coefficient of -0.301538 with a probability value of 0.0005 . DER also has a negative coefficient of -1.894500 with a probability value of 0.0032 . $C R$ has a negative coefficient of -0.020778 , with a probability value of 0.0028 .

According to the regression test result, the outcome shows that the F-test value is 40.8150700 and statistically significant, with a probability value of 0.0000 . As displayed in Table 7, the result of R-squared is 0.92699 . It means that all independent variables, which are ROA, DER, and CR provide $92.67 \%$ influences simultaneously towards firm value. The rest of $7.33 \%$ is influenced by other variables that are not examined in this study. 
Table 5.

Heteroscedasticity

\begin{tabular}{crrrr}
\hline Variable & Coefficients & Std. Error & t-Statistic & Prob. \\
\hline C & 0.712101 & 0.254883 & -0.774677 & 0.442600 \\
ROA & 0.022299 & 0.014735 & 1.513318 & 0.135800 \\
DER & -0.151069 & 0.122894 & -1.229263 & 0.224100 \\
CR & -0.000601 & 0.000573 & -1.048553 & 0.298900
\end{tabular}

\section{DISCUSSION}

As shown in the regression test results above, the firm value proxied by Tobin's $Q$ of Indonesian Insurance companies registered on the Indonesia Stock Exchange is affected by the ROA, DER, and CR.

\section{Effect of ROA on firm value}

The finding indicates that the ROA has a negative effect on firm value. These findings did not in line with hypothesis $\left(\mathrm{H}_{1}\right)$. This research result explained that higher profitability would be used by companies to invest and to expand business growth instead of distributing dividends to shareholders. Insurance companies with high profitability will reduce their dividend payout portion since the internal fund from profit will prefer to be used for investment or other operational costs. This condition will be responded negatively by the market and investor, and it explained why when companies have higher ROA, the firm value went down. Company's preference to use their internal sources to funds the investment or operational cost is consistent with the pecking order theory. Pecking order theory postulates that financing costs increase with asymmetric information. Three sources that have been known as financing sources are internal funds, debt, and new equity. From those sources of financing, companies will provide prominent their heads with these sequences; firstly, internal financing/funds, second, debt, and lastly, issued new equity as a "last resort."

The empirical results of the negative impact of ROA on firm value also can be found in Anggraini (2017), entitled Profitability effect on firm value with Mediating Capital Structure: Case Study in Jakarta Islamic Index 2012-2016.

\section{Effect of DER on firm value}

A high DER ratio reflects that the structure of total debt (both short and long-term) is higher than total capital itself, thus influencing the burden on companies to creditors. DER also supplies an overview of the company's capital structure, where we can see the risk level of unsettled debt and corporate debt. Companies with high debt simultaneously have a high cost of debt as well, and it has an impact on destroying the investor's confidence and trust level. Investors tend to avoid stocks with a high ratio in debt.

Table 6.

Partial regression test (t-test)

\begin{tabular}{crrrr}
\hline Variable & Coefficients & Std. Error & t-Statistic & Prob. \\
\hline C & 9.283470 & 1.847545 & 5.024760 & 0.0000 \\
ROA & -0.301538 & 0.079706 & -3.783111 & 0.0005 \\
DER & -1.894500 & 0.607674 & -3.117627 & 0.0032 \\
CR & -0.020778 & 0.006567 & -3.164251 & 0.0028
\end{tabular}


Table 7.

Simultaneous Regression Test (F-test)

\begin{tabular}{crcr}
\hline R-squared & 0.926997 & Mean depedent var & 2.026333 \\
Adjusted R-squared & 0.904285 & S.D. dependent var & 2.560404 \\
S.E. of regression & 0.792135 & Akaike info critetion & 2.584148 \\
Sum squared resid & 28.23651 & Schwarz criterion & 3.107735 \\
Log likelihood & -62.52445 & Hannan-Quinn ctiter. & 2.788952 \\
F-statistic & 40.81507 & Durbin-Watson Stat & 2.414051 \\
Prob(F-statistic) & 0.000000 & & \\
\hline
\end{tabular}

A regression test result between DER and firm value shows a negative and significant effect. The results of the research are in alignment with hypothesis $\left(\mathrm{H}_{2}\right)$. A negative considerable influence point toward that the higher firm's debt ratio will reduce firm value in certain ratio levels. This can be explained that leverage or loan usage will increase a company's value if the interest cost that occurred due to the loanable to reduce corporate taxes payment (create tax deduction), but in a certain level, if the debt/leverage continuously increase until exceeded optimum limit, thus the firm value will go down because an investor will see that the firm will have an obligation to pay installment and interest for that debt. This condition aligned with structured capital approach that stated $\mathrm{A}$ higher ratio of debt to assets will follow the higher company value reflected by its stock price in the market. But in a specific ratio, continuous increment in debt will not bring a higher increment in firm value because it causes higher risk in the company since higher loans will follow a higher risk of default. It will be making the value of the company getting lower. Or, in other words, increment leverage will increase the company's value to a certain level. Still, the continuously incremental leverage level after the optimum limit will reduce the company's value because it generated a higher risk of corporate debt. The empiric result of this research is aligned with a study conducted by Anggraini (2017), entitled Profitability effect on firm value with Mediating Capital Structure: Case Study in Jakarta Islamic Index 2012-2016, and also research from Mahendra (2012), entitled Effect financial performance on firm value in Manufacture companies listed in Indonesia Stock Exchange, both of the studies concluded that DER has negative and significant effect on firm value.

\section{Effect of CR on firm value}

A regression test result between $\mathrm{CR}$ and firm value shows a negative coefficient that is significant at a $5 \%$ level. These findings did not in line with hypothesis (H3). Accordingly, the higher of $C R$ value, the better it is for the company to fulfill short liabilities. The signaling theory states that a higher level of liquidity of the company proved that they could manage all available resources to maximize the company's operations. It will generate increased profitability and can be used to fulfill short-term liabilities. Nevertheless, a higher CR value will not be optimum at a certain level since it will because of idle money. Koh et al. (2014) explained that a higher current ratio could indicate that the firm has so many funds assigned in idle assets, such as securities or liquidity excessive. Besides, a high liquidity ratio can also be caused by significant investments but obsolete before being used. With this explanation, many shareholders do not want to maintain high liquidity ratios (Koh et al., 2014). The empiric result of the research aligns with the study conducted by Putra \& Sedana (2019), entitled Determinants of Profitability and Firm Value: Evidence from Banks of Indonesia which proved that liquidity has a significant and negative effect on a company value. This study's results are consistent with research conducted by Batten \&Vo (2019), which revealed a negative correlation between liquidity and company value. Higher or excessive liquid assets owned by the company can reduce firm value since excessive funds will be considered idle or non-productive assets.

Profitability from a company can be reduced if many idle funds are not being used in productive activities. This condition will be responded negatively by the market and investors. And it explained why when 
companies have higher $\mathrm{CR}$, the firm value went down.

\section{CONCLUSION}

This research aims to figure out the impact of ROA, DER, and CR on the firm value of insurance companies listed on the Indonesia Stock Exchange. The result of this study concludes that all these factors are a significant impact on firm value. The ROA has a negative and significant influence on the firm value of insurance companies. An increment in ROA will lead to a lower amount of firm value because large companies prefer to retain their earnings than to distribute their income as dividends. The companies prefer to maintain their earnings to distribute in other investment opportunities instead of payout of dividends. This action creates negative sentiment in the market and affects decreases company value. It also happens in DER and $C R$ factors; both factors have a negative and significant influence on the firm value. It means an increment in DER and CR will lead to a lower firm value. Increasing DER over the optimum scale will lead companies to bankruptcy, and this is not a good sign for investors, thus can bring lower firm value. In CR factor also has a similar phenomenon with DER. Increasing CR will lead to lower firm value since the higher $C R$ over the optimum scale indicates that the companies could not manage the cash and generate opportunity gain.

Overall, our empirical study found that the determinants of firm value in Indonesian insurance companies are similar to those of financial and non-financial institutions, documented previously in the existing literature. The result of this study provides valuable information for investors and corporations. For investors, they are advised to invest their funds in the companies that can generate maximum profits. Other factors related to management strategy in terms of ROA, DER, and CR should also be considered. Other than that, corporates management suggested making the best effort to achieve excellent financial performance, apply a balanced policy between earnings and dividends payout, and a balanced policy in the capital structure to attract investors to invest their funds in the company's stocks.

Of course, this research was hindered by several limitations. The first limitation of this research is related to the data coverage. The data used in this study is limited to insurance companies listed on the Indonesia Stock Exchange, so the results cannot be applied to all insurance companies or financial sectors. A second limitation is that the study only uses three independent variables of research: ROA, DER, and CR. Finally, there is also a limitation period examined in this study only from 2015-2019. For future research, we recommend including all insurance companies in Indonesia, both listed and non-listed in Indonesia Stock Exchange, as the research object and add more independent variables that influence the firm value, such as dividend payout ratio, fit size, and management structure.

\section{REFERENCES}

Acaravci (2015), Acaravci, S. K. (2015). The Determinants of Capital Structure: Evidence from the Turkish Manufacturing Sector. International Journal of Economics and Financial Issues, 5(1), 158-171.

Ang, Robert. 1997. Buku Pintar Pasar Modal Indonesia (The Intelligent Guide to Indonesian Capital Market). Jakarta: Mediasoft, Indonesia

Anggraini, R. D. (2017). Pengaruh Profitabilitas Terhadap Nilai Perusahaan Dengan Struktur Modal Sebagai Variabel Moderasi. 110. Jurnal Ekonomi, Universitas Sumatera Utara.

Annisa \& Chabachib (2017), Analisis Pengaruh Current Ratio (CR), Debt to Equity Ratio (DER), Return on Asset (ROA) Terhadap Price to Book Value (PBV), Dengan Devidend Payout Ratio (DPR) Sebagai Variable Interverning (Studi Kasus pada Perusahaan Industri Manufaktur yang Terdaftar. Journal of Management, 6, 1-15. Fakultas Ekonomi dan Bisnis, Jurusan Management Universitas Sam Ratulangi.

Basuki, A. T. (2017). Pengantar Ekonometrika. Alfabeta, Bandung.

Batten, Jonathan \& Vo, Xuan Vinh, (2019). Liquidity And Firm Value In An Emerging Market, The Singapore Economic Review (SER), World Scientific Publishing Co. Pte. Ltd., vol. 64(02), pages 365-376, March.

Bhattacharya and Dittmar (2004), Bhattacharya, Utpal dan Dittmar, Amy, (2001) Costless Versus Costly Signaling: Theory and 
Evidence from Share Repurchases, Seminar participants, Indiana University.

Brigham, E. F and J. F. Weston. (2010). Dasardasar Manajemen Keuangan, Edisi. 9, Erlangga.

Cahyono, D. D., \& Prabawa, S. A. (2011). Pengaruh ukuran Perusahaan, Profitabilitas, Pertumbuhan Asset, Dan Risiko Bisnis Terhadap Struktur Modal Pada Perusahaan Manufaktur Yang Terdaftar di BEI Periode 2008--2012. Jurnal IImiah Manajemen Universitas Bengkulu.

Cheung, A.W.K. (2011). Do stock investors value corporate sustainability? Evidence from an event study. Journal of Business Ethics, 99, 145- 165.

Culata, Priska R.E; and Gunarsih, Tri (2012), Pecking Order Theory and Trade-off Theory of Capital Structure: Evidence from Indonesian Stock Exchange, Universitas Teknologi Yogyakarta, Journal The WINNERS, Vol. 13 No. 1, Maret 2012: 40-49.

Dewantoro, A and Thaib, I (2017). Pengaruh Profitabilitas dan Likuiditas Terhadap Nilai Perusahaan dengan Struktur Modal Sebagai Variable Intervening. Jurnal Riset Perbankan Manajemen dan Akuntansi Vol.1.No.1

Ernayani et al., (2017), Formulation of a Dynamic Portfolio with Stocks and Fixed-Income Instruments in The Indonesian Capital Market, ISSN 2029-4581. Online ISSN 2345-0037, 2019, VOL. 10, No. 1(19).

Ernitasianturi, M. W. (2015). Pengaruh Kinerja Keuangan Terhadap Nilai Perusahaan Manufaktur Sektor Industri Barang Konsumsi Di BEl. EJournal IImu Administrasi Bisnis, 3(2), 282-296.

Fadhli, M. (2013). Pengaruh Likuiditas, Solvabilitas dan Profitabilitas Terhadap Nilai Perusahaan Dengan Kebijakan Deviden sebagai Variabel Moderasi Pada Perusahaan Perbankan, Asuransi dan Lembaga Keuangan Lainnya di Bursa Efek Indonesia Tahun 2010-2013. Jurnal Ekonomi Universitas Riau, 1-14.

Fajaria \& Isnalita (2018), (2018). The Effect Of Profitability, Liquidity, Leverage, And Firm Growth Of Firm Value With Its Dividend Policy As A Moderating Variable. International Journal of Managerial Studies And Research (ljmsr), 6(10), 55-69.

Ghozali, I. (2013). Analisis Multivariat dan Ekonometrika Teori, Konsep dan Aplikasi dengan Eviews 8. Universitas Diponegoro. Semarang.
Gitman and Zutter (2012). Principles of Managerial Finance. United States: Pearson Addison Wesley.

Hamidah, G., \& Umdiana, N. (2017). Pengaruh Profitabilitas Dan Investmen Opportunity Set Terhadap Nilai Perusahaan Dengan Harga Saham Sebagai Intervening. Jurnal Akuntansi, 3(2), 90-106.

Handriani, E., \& Irianti, T. E. (2015). Investment Opportunity Set Bebasis Pertumbuhan Perusahaan Dan Kaitannya Dengan Upaya Peningkatan Nilai Perusahaan. Ekonomi Dan Bisnis, XVIII(1).

Harmono (2011), Manajemen Keuangan: Berbasis Balanced Scorecard Pendekatan Teori, Kasus dan Riset Bisnis.BPFE, Yogyakarta.

Hasbi, Hariandy. (2015). Islamic Microfinance Institution: The Capital Structure, Growth, Performance, and Value of Firm In Indonesia. ScienceDirect: Procedia Social and Behavioral Sciences 211. Pp 1073-1080.

Hermawan, S., \& Maf'ulah, A. N. (2014). Pengaruh Kinerja Keuangan Terhadap Nilai Perusahaan Dengan Pengungkapan Corporate Social Responsibility sebagai Variabel Pemoderasi. Jurnal Dinamika Akuntansi. Universitas Pendidikan Indonesia; Journal of Business Management Education.

Hertina, D., Bayu, M., Hidayat, H., \& Mustika, D. (2019). Ukuran Perusahaan, Kebijakan Hutang Dan Profitabilitas Pengaruhnya Terhadap Nilai Perusahaan. Jurnal Ecodemica, 3(1).

Hery. (2016). Analisis Laporan KeuanganIntegrated And Comprehensive Edition. PT. Grasindo, Jakarta.

Hossain, Akhtaruddin M., and Hossain, M., (2015). "Corporate Governance and Voluntary Disclosure in Annual Corporate Reports of Malaysian Listed Firms." Journal of Applied Management Accounting Research, (Winter):1-20.

Jacoby, G. and Zheng, S.X. (2013). Ownership dispersion and market liquidity. International Review of Financial Analysis. Vol. 19 No. 2, pp. 81-88.

Kasmir (2014), Bank dan Lembaga Keuangan lainnya. Jakarta: PT. Raja Grafindo Persada.

Koh, Annie., Ser-Keng Ang, Eugene F Brigham, Michael C Ehrhardt. (2014). Financial Management Theory and Practice. Singapore: Cengange Learning Asia. 
Mahendra, A. D. (2012). Pengaruh Kinerja Keuangan Terhadap Nilai Perusahaan Pada Perusahaan Manufaktur di Bursa Efek Indonesia. 130-138. Vol. 7, No. 2, Juli 2012. AUDI Jurnal Akuntansi \& Bisnis.

Mardiyati, Umi; Gatot Nazir Ahmad dan Ria Putri. (2012). Pengaruh Kebijakan Dividen, Kebijakan Hutang dan Profitabilitas terhadap Nilai Perusahaan Manufaktur Yang Terdaftar Di Bursa Efek Indonesia (BEI) Periode 2005- 2010. Jurnal Riset Manajemen Sains Indonesia (JRMSI): Vol. 3, No. 1.

Miller \& Modigliani -MM (1961) Modigliani, F., and Miller, H. (1963). Corporate in $\neg$ come taxes and the cost of capital: a correction, American Economic Review, Vol. 53: 443-453.

Myers, S. C. (1984). The Capital Structure Puzzle. Journal of Finance, 39(3), 575592.

Myers, S. C., \& Majluf, N. S. (1984). Corporate Financing and Investment Decisions When Firms Have Information the Investors Do Not Have. Journal of Financial Economics, 13(2), 187-221.

Pervaiz, Akhtar., Husnain, Muhammad and Mukhtar, Muhammad Ahsan. (2012). The Determinants of Capital Structure: A Case from Pakistan Textile Sector (Spinning Units). International Conference on Business Management.

Prasetyorini, B. F. (2013). Pengaruh Ukuran Perusahaan Leverage, Price Earning Ratio dan Profitabilitas terhadap Nilai Perusahaan. Jurnal Riset Akuntansi Indonesia. Volume 7 Nomor 2.

Pratiwi, P. (2018). Pengaruh struktur kepemilikan terhadap nilai perusahaan dengan kebijakan hutang sebagai variabel intervening. JOM FISIP, Vol.4, No.2, 111.

Putra \& Sedana (2019), Candradewi, Bagus, \& Sedana. (2016). ISSN : 2302-8912 Pengaruh Kepemilikan Manajerial, Kepemilikan Institusional Dan Dewan Komisaris Independen Terhadap Return On Asset Fakultas Ekonomi Dan Bisnis Universitas Udayana ( Unud), Bali , Indonesia Menghadapi persaingan bisnis yang kompetitif ,. EJurnal Manajemen Unud, 5(5), 3163-3190.

Sastrodiharjo and Sutama, (2015), Sastrodiharjo, Istianingsih dan Sutama, I Putu. 2015. Faktor-faktor yang Memepengaruhi Pertumbuhan Aset Perusahaan Asuransi Jiwa Syariah Di Indonesia. Jurnal Akuntabilitas. Vol. VII. No. 1.
Sugiono. (2012). Statistik Untuk Penelitian. Alfabeta; Bandung.

Sulasmiyati, S. (2016). Pengaruh struktur modal, struktur kepemilikan dan profitabilitas terhadap nilai perusahaan pada perusahaan sektor industri dasar dan kimia yang terdaftar di BEI tahun 2011 2014. 35(1). Universitas Muhammadiyah Surakarta.

Sunaryo, D., \& Adiyanto, Y. (2017). Pengaruh Debt to Equity Ratio (DER) dan Deviden Payout Ratio (DPR) Terhadap Nilai PerusahaanPada Manufaktur Sektor Indusrti Untuk Konsumsi yang Terdaftar di BEI Tahun 2012 - 2017. Universitas Muhammadiyah Surakarta, 33-53.

Tahu, G. P., \& Susilo, D. D. B. (2017). Effect of Liquidity, Leverage, and Profitability To The Firm Value (Dividend Policy As Moderating Variable) In Manufacturing Company Of Indonesia Stock Exchange. Research Journal of Finance and Accounting, 8(18), 89-98.

Torres-Reyna, O. (2014). Panel Data Analysis Fixed \& Random Effects. Princeton University.

Ulya, H. (2014). Analisis Pengaruh Kebijakan Hutang, Kebijakan Deviden, Profitabilitas, Kinerja Perusahaan dan Keputusan Investasi Terhadap Nilai Perusahaan.

Yanti Asmita, N. Y., \& Dwirandra, A. (2019). The Effect of Profitability in Income Smoothing Practice with Good Corporate Governance and Dividend of Payout Ratio as a Moderation Variable. International Research Journal of Management, IT and Social Sciences, 6(2), 12-21.

Yaomil, Grace F (2019), Pengaruh intellectual capital dan corporate governance terhadap kinerja keuangan perusahaan (studi pada perusahaan indeks LQ-45 periode 2013-2017), FEB Usakti, Jakarta.

Zuhroh (2019), The Effects of Liquidity, Firm Size, and Profitability on the Firm Value with Mediating DOI: $10.18502 / \mathrm{kss} . v 3 i 13.4206$. 